\title{
Assessment of Effect of Maternal Employment on Nutritional Status of Under Five Children In Mendera Kochi Kebele, Jimma Town, Jimma Zone, Ethiopia: Community Based Cross Sectional Study
}

Bekana Fekecha Hurissa ( $\nabla$ bekf@rocketmail.com )

Jimma University

Haregwa Asnake

Jimma University

\section{Research}

Keywords: Nutritional status; Maternal employment; Under-five children; anthropometric measurements

Posted Date: April 2nd, 2020

DOI: https://doi.org/10.21203/rs.3.rs-20033/v1

License: (c) (1) This work is licensed under a Creative Commons Attribution 4.0 International License.

Read Full License 


\section{Abstract}

Background: Malnutrition continues to be a critical public health problem in sub-Saharan Africa. For example, in East Africa, $48 \%$ of children under- five are stunted while $36 \%$ are under weight. Poor health and poor nutrition are now more characteristics of children living in urban area than of children in rural areas. Therefore this study assessed the effect of maternal employment on nutritional status of underfive children at Mendera Kochi kebele of Jimma town South West of Ethiopia.

Method: Community based cross sectional study design was conducted in Jimma town Mendera Kochi kebele from April15-May 05. Systematic sampling technique was used. Pre-tested structured questionnaires used for data collection. A total of 264 study subjects were interviewed. The collected data analyzed using SPSS 20 version.

Result: Out of 264 total households the majority, 96(36.4\%) of mothers were living in households with 3-4 or more family members. Out of 264 respondents 155(58.7\%) were government employee, $93(35.3 \%)$ and the remaining were private and NGO employees. The income level of majority of respondents, $54.5 \%$ was between 1000 and1500. A total of 254 children aged 0-59 months were enrolled in this study. The age of the children in the study area, 6-12 months $89(35 \%), 12-24$ months $111(43.6 \%)$, and $24-59$ months $54(21.4 \%)$ respectively. Weight of children's $53(21.1 \%)$ were between $1500-2500 \mathrm{gm}, 40(16.1 \%)$ were between $2500-4000 \mathrm{gm}, 25(9.8 \%$ ) were $>4000 \mathrm{gm}$ and the rest were below $1500 \mathrm{gm}$. $151(57.2 \%)$ children of working mothers had a mean upper arm circumference value of $>=12.5 .51 .1 \%$ of the children had height for age ranged from $90-95 \%$ percentiles.

Conclusion- The children of working mothers were observed to achieve better nutritional status from their anthropometric measurement. Maternal employment is not a protective factor against diarrhea and acute respiratory infection.

\section{Introduction}

Nutrition has special significance in countries with disadvantages in socioeconomic and hygienic standards. The problems of poverty, safe drinking water, environmental hygiene and poor literacy contribute to the problems of nutrition and public health (1). Hunger and malnutrition are devastating problems, particularly for the poor and underprivileged (2). Anthropometry evaluates long term nutritional history with rapid, accurate, reliable and quantitative means of nutritional assessment, which is useful in monitoring normal growth and nutritional health in well-nourished individuals. Nutritional anthropometry is of vital importance in growth failure and under nutrition. The state of nutrition both under and over can be detected objectively by studying the characteristics of each age group - weight, height, various circumferences and skin folds. Nutritional anthropometry is defined as measurements of variations of the physical dimensions and the gross composition of the human body at different age levels and degree of nutrition $(3,4)$. 
Childhood and women during pregnancy and lactation are supposed to vulnerability to malnutrition $(5,6)$. Chronic under nutrition occurs when long term food consumption is insufficient to meet the energy requirements, on a daily basis for daily energy expenditure. It is usually assessed in terms of body measurements in adults - in thinness; in children - stunting. Nutritional status of children is linked with the mothers'. Good nutrition of women is not only essential for the wellbeing of women, is also an important factor determining the growth and development of their children in uterus and as young children (9). The conditions of poverty, most importantly the high proportion of women working away from home, the dependence on cash income and the deteriorating environmental conditions pose special challenges to the care of children. The nutrition, growth and development of infants and young children depend not only on sufficient food, but also on adequate health services and appropriate care behaviors(9).

Women's participation in the work force in developing countries has been increasing steadily over the last several decades (12). On global basis 42\% of women over age 15 are in the labor force. African women, produce as much as $80 \%$ of the food, and supplement family income by working in the formal and informal sectors as traders and producers (13).

In developing countries, the percentage of women in the paid labor force increased from $28 \%$ in 1950 to $32 \%$ in $1985,54 \%$ in 1996 and $63 \%$ in $2011(14,15)$.

In Ethiopia, in the rural area $85 \%$ of the women involved in agricultural work, while in the urban areas due to various social crises as well as rural urban migration, about $35 \%$ of urban dwellers are women. This huge work force was forced to engage in low skills, education and inability to compete with their male counter parts (16).

Nutritional problems, including malnutrition and under-nutrition, have the major health and welfare problems facing developing countries for the last fifty years (17). Malnutrition is complex in its etiology and cumulative in its manifestations. It not only impairs physical and intellectual performance, but also causes considerable ill health and contributes significantly to child morbidity and mortality. Thus, malnutrition continues to be a problem of considerable magnitude in most developing countries. Among the population, children suffer the most from effects of malnutrition and diarrhea, which often coexist, so much, so that it remains to be the main source of suffering, disability and death (11)

To date, they remain to be the main sources of suffering, disability and death, particularly among children and mothers in most developing countries. The fact that women have dual responsibilities placed on them; to provide care and to provide income; justifies a particular focus on the relation of women's work to child outcomes. According to a report by UNICEF, this "silent emergency"- malnutrition, with other diseases, causes 40,000 child deaths every day with another 150 million children living with ill health and poor growth. One-fourth of child deaths in the world, one-third of child deaths in Africa are attributed to malnutrition $(18,19)$. About $25 \%$ of the World's under-five children are described as malnourished (20). 
Concern for the dual role of woman in developing societies, both as income earner and family care provider, has recently emerged as an important factor in development planning. Focusing on nutrition, it would appear that increased income should lead to improved family welfare, and thus, too improved child dietary intake and nutritional status.

Therefore, there is an argument that income earned by mother or maternal employment has a direct effect on childcare, nutritional status of children and the mother themselves. Such argument, however, has not been substantiated by studies from developing countries (21).

Very few studies however indicated that the nutritional status of children of working and non-working mothers was not significantly different (27).

Different studies showed that women's employment might exert influence on household nutrition through increased status, power autonomy of decision-making ability (28).

Different literatures revealed that the relationship between maternal work status, well-being, and nutritional status of children are complex issue surrounded with controversies. The Ethiopian government policy on women aims at creating an opportunity that encourages women's participation in the labor force. Hence, the percentage of women in the labor force is increasing from time to time. Therefore, it would be of interest to find out whether the well being of children affected more by the time constraints of women working, or by the increased income generated by the mother's working particularly in urban setting. Hence, with this understanding this study was initiated. Therefore, in this study, maternal work status was examined in relation to nutritional (anthropometrics) and health status of children (29).

\section{Materials And Methods}

Community based cross sectional study was conducted on randomly selected 264 women of reproductive age (15-49) who have under five children within selected households. Single population proportion formula was used to determine the required sample size with the assumptions, $P=$ the national prevalence to the lowest level in Addis Ababa of malnutrition 22\% (30), $d=$ Degree of accuracy required (sampling error) $5 \%$ i.e. $d=0.05 ., Z=$ Standard score for $95 \%$ confidence level 1.96., Number of households of the kebele 2, 926. This gave a sample size of $n=(1.96)^{2 \star 0.22}(1-0.22) /(0.05)^{2}=264$. By using correction formula, $\mathrm{nf}=\mathrm{n} / 1+\mathrm{n} / \mathrm{N}$

Where: $\mathrm{nf}=$ final sample size, $\mathrm{n}=$ initial sample size, $\mathrm{N}=$ total household, $\mathrm{nf}=264 \div(1+(264 / 2,926)\}=240$. With $10 \%$ contingency, $\mathrm{nf}=240+24=264$ was the final sample size. Systemic sampling technique was used. Dividing the total number of household for the calculated sample size, $(2,926 / 264) \mathrm{k}$ interval obtained $(K \sim 11)$. The first house was selected by simple lottery method.

The data collection conducted through face to face interview using pre-tested structured questionnaire adopted from previous studies and translated to local language. 
Data collectors (five Midwifery students and one MSc nutrition expert) additionally utilized Measuring tape and MUAC measurement for detecting under five children's nutritional statuses. Data collectors trained before actual data collection.

To maintain the quality of data pre-test was done on $5 \%$ of the sample. After data collection, each questionnaire was checked for completeness, edited, cleaned for missed values and missed variables and analyzed using SPSS version 20 for frequencies and percentages for categorical variables and means for numerical variables and the result was presented using tables, figures and texts.

\section{Result}

\section{Socio- demographic of respondents}

Out of 264 total households the majority, 103(40.7\%) of mothers were Muslims. Majority of mothers 98 (38.6) can read and write, Illiterate 90 (35\%), Primary 39 (15.4\%) and the rest were secondary, tertiary and above. Oromo was the dominant ethnicity constituting 220 (86.6\%) followed by Dawro 19 (7.5\%) and other ethnic groups 15 (5.9\%). With respect to marital status, more than half were married $194(73.6 \%)$ and the rests were single. Most mothers, $117(44.5 \%)$ were aged $25-30$ years and more. About $96(36.4 \%)$ of mothers were living in households with 3-4 or more family members. Out of 264 respondents $155(58.7 \%)$ were government employee, $93(35.3 \%)$ and the remaining were private and NGO employee. The income level of majority of respondents was between 1000 and1500 which is (54.5\%).

\section{Distribution of mothers' employment}

From all working mothers, 33(21.3\%) of them were working the whole week, while 105(93.7\%) of them still need support from their husband (Table 1). 
Table 1

Distribution of mothers by employment in the last 12 months, Jimma south west Ethiopia, May 2017.

\begin{tabular}{|lllll|}
\hline & & No of days doing work per week & Frequency & $\%$ \\
\hline Employed mothers & Yes & $1-2$ days & 26 & $17.1 \%$ \\
\cline { 2 - 4 } & & $3-5$ days & 96 & $63.2 \%$ \\
\cline { 2 - 4 } & The whole week & 33 & $21.3 \%$ \\
\cline { 2 - 4 } & TOTAL & 155 & $100 \%$ \\
\cline { 2 - 4 } & From husband & 105 & $93.7 \%$ \\
\cline { 2 - 3 } & From relatives & 4 & $3.6 \%$ \\
\cline { 2 - 4 } & Help from others & 3 & $2.7 \%$ \\
\cline { 2 - 3 } & TOTAL & 112 & \\
\hline
\end{tabular}

\section{Characteristics and Feeding pattern of under five children}

A total of 254 children aged 0-59 months were enrolled in this study. $46.1 \%$ and $53.9 \%$ were (Males) and (Females), respectively. The age of the children in the study area was 6-12 months 89(35\%), 12-24 months $111(43.6 \%)$, and 24-59 months 54(21.4\%) respectively. Concerning place of delivery, out of 264 respondents $155(58.9 \%)$ mothers were delivered at health institutions. The remaining delivered at home being assisted either by traditional trained birth attendants (TTBA), traditional birth attendants (TBA), and/or relatives. According to mother's information 147(57.9\%) children were measured at birth for their weight. Hence, from children whose weight was measured, 53(21.1\%) were between 1500-2500 gm, 40(16.1\%) were between 2500-4000 gm, 25(9.8\%) were > $4000 \mathrm{gm}$ and the rest were below $1500 \mathrm{gm}$.

Employed mothers Child diagnosis with nutritional related illness indicated that most of them 25(39.7\%) and $20(31.7 \%)$ were due to poverty and lack of adequate care respectively (Table 2). Most of the mothers, $123(48.4 \%$ ) breast fed within the interval of $4-6$ months (see Table 3$) .77(29 \%)$ of those mothers reporting having worked outside home in last12 months started introduction of weaning $<6$ months(Table 5). $155(61 \%)$ of the mothers vaccinated their child at six weeks of their birth(Table 7$) .51 .1 \%$ height for age of children's of working mothers were ranged from $90-95 \%$ percentiles( Fig. 1). 
Table 2

Distribution of under five children by nutritional status, Jimma south west of Ethiopia, May 2017.

\begin{tabular}{|c|c|c|c|c|}
\hline & & & Frequency & $\%$ \\
\hline \multirow{7}{*}{$\begin{array}{l}\text { Child diagnosis with nutritional related } \\
\text { illness }\end{array}$} & \multirow[t]{6}{*}{ YES } & Lack of adequate care & 20 & $31.7 \%$ \\
\hline & & $\begin{array}{l}\text { Inadequate breast milk } \\
\text { feeding }\end{array}$ & 15 & $23.8 \%$ \\
\hline & & Poverty & 25 & $39.7 \%$ \\
\hline & & Chronic medical Illness & 2 & $3.2 \%$ \\
\hline & & Other & 1 & $1.6 \%$ \\
\hline & & Total & 63 & $100 \%$ \\
\hline & No & Total & 201 & $76.3 \%$ \\
\hline
\end{tabular}


Table 3

Distribution of under five children by their breast feeding time in months in Jimma South West Ethiopia, May 2017.

\begin{tabular}{|c|c|c|c|c|}
\hline Variables & & & Frequency & $\%$ \\
\hline \multirow[t]{7}{*}{ Breast feed the child } & \multirow[t]{6}{*}{ Yes } & $\begin{array}{l}\text { Less than four } \\
\text { months }\end{array}$ & 25 & 9.8 \\
\hline & & 4-6 months & 123 & $48.4 \%$ \\
\hline & & 7-9 months & 49 & $19.3 \%$ \\
\hline & & $10-12$ months & 25 & $9.8 \%$ \\
\hline & & $>12$ months & 30 & $11.9 \%$ \\
\hline & & Total & 252 & $99.2 \%$ \\
\hline & \multicolumn{2}{|l|}{ No } & 2 & $0.8 \%$ \\
\hline \multirow{4}{*}{\multicolumn{2}{|c|}{ Duration of exclusive breast feeding }} & $<2$ months & 5 & $1.97 \%$ \\
\hline & & $<4$ months & 41 & $16.1 \%$ \\
\hline & & $<=6$ months & 204 & $80.3 \%$ \\
\hline & & $>6$ months & 2 & $0.8 \%$ \\
\hline \multirow{4}{*}{\multicolumn{2}{|c|}{ Age of child weaned }} & $<2$ months & 5 & $1.97 \%$ \\
\hline & & 2-4months & 25 & $9.8 \%$ \\
\hline & & 4-6months & 26 & $10.2 \%$ \\
\hline & & $>6$ months & 196 & $77.2 \%$ \\
\hline \multirow{4}{*}{$\begin{array}{l}\text { Frequency of breast feeding during day light } \\
\text { hours on working days }\end{array}$} & & $<2$ times & 4 & $1.6 \%$ \\
\hline & & $3-4$ times & 55 & $21.6 \%$ \\
\hline & & $5-6$ times & 155 & $61 \%$ \\
\hline & & $>6$ times & 38 & $14.96 \%$ \\
\hline
\end{tabular}

\section{Childhood diseases}

Three illnesses that are of major importance for infant and child survival that have been found in the survey were, fever, acute respiratory infection (ARI), and diarrhea.

The prevalence of acute respiratory infection was estimated by asking mothers if their children under-five had cough with short and rapid breathing in the two weeks preceding the survey. These symptoms were compatible with pneumonia. It should be born in mind that morbidity data collected in the survey were 
subjective, i.e., dependent on mothers' perception of illness, and not validated by medical personnel. Out of 254 total children of the age of under five only 5 (1.96\%) children has been ill in the last two weeks before the data collection, the commonest one was ARI $4(80 \%)$. 3(60\%) of them were seek treatment in government health institution. $47(17 \%)$ of mothers reporting having worked outside home within last 12 months reported their children's Childhood illnesses (Table 4)

Table 4

Distribution of mothers by working characteristics, under five children breast feeding time and child hood illness, Jimma south west of Ethiopia, May 2017.

\begin{tabular}{|llllll|}
\hline Variable & category & Frequency & & & Total \\
\hline $\begin{array}{l}\text { Have you taken any job outside home } \\
\text { last12 months }\end{array}$ & $\begin{array}{l}\text { Breast } \\
\text { feeding }\end{array}$ & $\begin{array}{l}2-4 \\
\text { month }\end{array}$ & $\begin{array}{l}4-6 \\
\text { months }\end{array}$ & $\begin{array}{l}\text { >6 } \\
\text { months }\end{array}$ \\
\cline { 2 - 6 } & Yes & 25 & 42 & 88 & 155 \\
& No & 13 & 51 & 45 & 109 \\
& Child hood & Yes & No & Don't \\
& illness & & & know & \\
& Yes & 47 & 107 & 1 & 155 \\
$\begin{array}{l}\text { Have you taken any job outside home } \\
\text { last12 months }\end{array}$ & No & 42 & 55 & 12 & 109 \\
\hline
\end{tabular}

Table 5

Distribution of mothers by working characteristics and introduction of weaning for under five children, Jimma south west of Ethiopia, May 2017.

\begin{tabular}{|llllll|}
\hline Variable & category & Frequency & & & Total \\
& Introduction of & $<6$ & $12-24$ & $>$ \\
& weaning & months & months & 24 months & \\
Have you taken any jop outside & Yes & 77 & 43 & 35 & 155 \\
home last12 months & No & 4 & 60 & 45 & 109 \\
\hline
\end{tabular}

\section{Nutritional Status Description}

Anthropometrics data showed that, the children of working mothers observed to achieve better nutritional status as based on their MUAC measurement. 151(57.2\%) of them had a measurement value of >= 12.5(Table 6). 
Table 6

Distribution of mothers by working characteristics and under five children by MUAC measurement, Jimma south west of Ethiopia, May 2017.

\begin{tabular}{|llllll|}
\hline Variable & category & Frequency & & & Total \\
& MUAC & $>=12.5$ & $11-$ & $<$ \\
& & & 12.5 & 11 & \\
\hline $\begin{array}{l}\text { Have you taken any job outside home last12 } \\
\text { months }\end{array}$ & Yes & 151 & 2 & 2 & 155 \\
\hline
\end{tabular}

Table 7

Distribution of under five children by taking of vaccination, Jimma south west of Ethiopia, May 2017.

\begin{tabular}{|lllll|}
\hline & \multicolumn{2}{c}{ Time of taking vaccination } & Frequency & $\%$ \\
\hline Is your child vaccinated & Yes & Within two weeks of birth & 2 & $0.78 \%$ \\
& & At six weeks of birth & 155 & $61 \%$ \\
& At ten weeks of birth & 25 & $9.8 \%$ \\
& At 14 weeks of birth & 25 & $9.8 \%$ \\
& At 9 months of birth & 15 & $5.9 \%$ \\
\hline No & Total & 222 & $87.4 \%$ \\
\hline & Total & 32 & $12.6 \%$ \\
\hline
\end{tabular}

\section{Discussion}

The study has been attempted to assess the effect of maternal employment on nutritional status of under five children. The overall result showed that the prevalence of stunting was $7.4 \%$ children. Children of working mothers were seen to have a better nutritional status with done anthropometric measurements. Numerous studies have found that children of working mothers have a lower nutrition status $(18,22$, and 24$)$. Others however, have found maternal employment outside the home to have a positive impact on children's nutrition status $(27,32)$.

It is also believed that economically independent women are more likely to use their knowledge to maintain good nutrition. The overall nutritional status of children of working mothers is significantly better, particularly height-for-age were positively associated with maternal employment. This could be due to the fact that maternal employment increases economic gain of a mother that has a positive impact on children's dietary intake and anthropometry. This finding was consistent with other studies done in other country $(27,32,33$, and 20$)$. In relation with maternal employment the household economy could be an important factor for the welfare and nutritional status of children. This finding was also consistent with the results obtained in a study done in Bangladesh (2). 
The pattern of infant feeding has important influences on nutritional status of children. Feeding practices are among the principal determinants of child nutrition. These effects are influenced by the age at which the child receives liquid and solid food supplementations. In this regard, due to variations in maternal time, the majority of working mothers started feeding their children with liquids and foods supplementations earlier before the age of weaning and also early termination of breastfeeding was observed more in working mothers. This could be due to the fact that the occupation in which working mothers engaged was not compatible in such a way that mothers were able to continue to care for the child while working or return home to supervise child care. Thus, working mothers were obliged to leave their children with somebody else who care for their children. Extensive body research suggests that if adequate alternative childcare is available, there are no negative impacts of mother's employment on the child (41). However, in the much more economically and environmentally stressed situation in which many Ethiopian women live, this conclusion may not hold.

Therefore, due to all these facts, children of working mothers were at the disadvantage with regard to childcare and feeding practices. Thus, these inappropriate feeding practices increase the chance of child's malnutrition (37)

\section{Conclusion}

The children of working mothers were observed to have better nutritional status from their anthropometric measurements with higher MUAC values. 151(57.2\%) of the children had a mean upper arm circumference of $>=12.5 .51 .1 \%$ of the children had height for age measurement within $90-95 \%$ percentiles. This study evaluated working mothers feeding practices, including duration of their breastfeeding, and time of their initiation of supplementary weaning foods. It showed that working mothers were more likely to initiate weaning earlier. Maternal employment was not found as a protective factor against childhood illnesses such as diarrhea and acute respiratory infection.

\section{Lists Of Abbreviations}

ARI - Acute Respiratory Infection

BOD - Global Burden of Diseases

JUSH-Jimma University Specialized Hospital

ETB - Ethiopian Birr

$\mathrm{HH}$ - Households

F - Female

M - Male

MUAC - Middle Upper Arm Circumference 
NCHS - National Children Health status

PEM - Protein Energy Malnutrition

UNICEF - United Nations International Children Emergency Fund

WHO - World Health Organizations

NGO - Non-Governmental Organization

BMI-Body Mass Index

MDG-Millennium Development Goal

HIV-Human Immune Virus

NDHS-National Demographic and Health Survey

AIDS- Acquired Immune Deficiency Syndrome

IFPRI-International Food Policy Research Institute

ANCOVA-Analysis of Covariance

\section{Declarations}

\section{Ethics approval and consent to participate}

Ethical clearance for the study was obtained from Jimma University. Official letter was obtained from Mendera Kochi Kebele administration to get permission and the first page of the questionnaire was providing full information to the study participants regarding the purpose and nature of the research. Verbal consent was obtained from each participant. Participation to the study was on voluntary basis, and participants was informed about their right not to participate in the study if they did not want to participate and the right to withdraw from the study at any point of the interview. Moreover, confidentiality of the information was assured through using anonymous questionnaires and keeping the data in secured place.

\section{Consent for publication}

Not Applicable.

\section{Availability of data and materials}

The datasets used and/or analysed during the current study are available from the corresponding author on reasonable request. 


\section{Competing Interests}

The authors declare that they have no competing interests.

\section{Funding}

The study was funded by Jimma University. The funder has no role in the design of the study and collection, analysis, and interpretation of data and in writing the manuscript.

\section{Authors' Contributions}

Both authors participated in the design and analysis of the study. HA searched the databases, and wrote the first and second draft of the article. BF reviewed proposal development activities and each drafts of the result article. Both authors revised the manuscript and approved the final version.

\section{Acknowledgements}

First and for most we would like to thank the almighty God for initiating us for doing this research thesis on such a burning issue of Nutritional Status of Under Five Children. We would like to extend our thanks to Jimma University School of nursing and midwifery and student research project (SRP) for giving us this opportunity to conduct this study and for funding it. Last but not least we would like to extend our appreciation to all our family friends for their support and encouragement during this research work.

\section{Authors' Information}

\section{Affiliations}

1.Jimma University, Institute of health, College of Health Science, School of Nursing and Midwifery, South West, Ethiopia. P.O.BOX:378, Jimma Ethiopia. Bekana Fekecha

2.Jimma University, Institute of health, College of Health Science, School of Nursing and Midwifery, South West, Ethiopia. Haregwa Asnake

\section{References}

1. Yasoda P, Geervani G. Determinants of nutrition status of rural preschool children in Andhra, Pradesh, India. Food and Nutrition Bulletin; 2005.

2. Piechulek H, Mendoza J, Hasan N. Feeding practices and malnutrition in children in rural Bangladesh. Food and Nutrition Bulletin; 2008.

3. Third Report on the World Nutrition Situation, December 2002

4. Economic commission for Africa. Africa: Fostering Women's Economic Empowerment through Exchange Visit and Networking, Submitted by; The Africa American Institute (AAI). April; 2013. 
5. Leonardo A, Chen M, Buvini ME, Jahan R, Mosses C, Staudik. Supporting women's work around the world, 2012.

6. Food and nutrition strategy and policy issues, Addis Ababa: 14-15, 2010

7. Diet, Nutrition and Prevention of Chronic Diseases. Technical Report Series 797; 2007.

8. The World Bank. Better Health in Africa. Washington Dc. .

9. The World Bank. World Development Report: Investing In Health. Oxford Univ. Press, 2005

10. Anandalakshmy, S., ed.The girl child and the family. An action research study. Delhi, India: Department of Women and Child Development, Ministry of Human Resource Development, Government of India 1994

11. Bennett L. The role of Women in Income Production and Intra-household Allocation of Resources as a Determinant of Child Nutrition and health. Food Nutr Bull, 2005

12. Thailand: managing public resources for structural adjustment. World Bank Country Study. Washington, DC: World Bank, 2006.

13. Hutaserani S, Jitsuchon S. Thailand's income distribution and poverty profile and their current situations. Bangkok: Thailand Development Research Institute. 2002.

14. Macroeconomic Policy Program. The outlook for the Thai economy. TDRI year-end conference, "Thailand in the International Economic Community," Bangkok: Thailand Development Research Institute, 2005.

15. FAO production yearbook. Rome: Food and agriculture organization, 2001.

16. Ricci JA, Jerome NW, Sirageldin I, Aly H, Moussa W, Galal O, Kirksey A. The Significance of Children's Age in Estimating the Effect of Maternal Time Use on.

17. N Samrawit. The Effect of Maternal Work on Nutritional Status of mothers and Children, thesis presented to the school of graduate studies, A. A.U. inpartial fulfillment of the requirement for the degree of master of public health, 2010.

18. Seyoum E, Kidanne $Y$ and Gebru H, Sevenhayen G. Preliminary Study of Income and Nutritional Status Indicators in two Ethiopian Communities. Food Nutrition Bulletin, 2009.

19. Doan RM, Bishara L. Female Autonomy and Children Nutritional Status. The Extended family Residential Unit in Amman Jordan. Soc. Sci. Med.2007.

20. Johnson Fc. Rogers BI. Children's Nutritional Status in Female Headed household in the Dominican Republic. Soc. Sci. Med.2009.

21. Onyango A, Tucker K, Eiseman T. Household Headship and child Nutrition. A Case Study in West Kenya. Soc. Sci. Med.2004.

22. Chatterjee M, Lambert J. Women and Nutrition Reflection from India and Pakistan. Food and Nutrition Bulletin. 2010.

23. Katherine Tuker and Diva Sanjur. Maternal Employment and child Nutrition in Panama. Soc. Sci. Med. 2009.

24. CSA (Ethiopian Central Statistical Agency). Demographic and Health Survey, Ethiopia; 2011. 
25. UNICEF (United Nations Children's Fund). Strategies of improving nutrition of children and women in developing countries. New York; 2005.

26. Patricia S. Environmental Factors and Children's Malnutrition in Ethiopia. Policy Research working papers; 2005.

27. Gugsa Y. Malnutrition among children in southern Ethiopia: Levels and risk factors. Ethiop. J. Health Dev 2000.

28. Central Statistical Authority (CSA), Report on the 1998 Health and Nutrition Survey; Addis Ababa, 2007

29. ACC/SCN. Third Report on the World Nutrition Situation. December 2006.

30. Human nutrition in the developing world. Michael C. Latham. FAO Food and nutrition series; 2010.

31. Quisumbing AR, Brown LR, Feldstein HS, Haddad L, Penna C. Women and Economic Access to Food. Food Policy Report, the Key to Food Security. Washington, D.C, August, 2005.

32. Jessica F. Lamontagne, Patrice L. Engle and Marian F. Zeitlin. Maternal employment, Child Care, and Nutritional status of 12-18 month-old Children in Managua, Nicaragua. Soc. Sci. Med. 2009.

33. Engle PL. Influences of Mothers' and Fathers' Income on Children's Nutritional Status in Guatemala. Soc. Sci. Med. 2009.

34. Mc Guire J. Popkin BM. Beating the Zero Sum game. Women and Nutrition in the Third World. Administrative committed on coordination/subcommittee on Nutrition (ACC/SCN) Symposium Report Nutrition Policy Discussion paper, October; 2003.

35. Powell CA, Mc Gregor SG. The ecology of Nutritional Status and Development in Young Children in Kingston, Jamica. The American Journal of Clinical Nutrition, 2012.

36. Bisgrove EZ, Popkin BM. Does Women Work Improve Their Nutritional: Evidence from The urban Philippines Soc. Sci. Med. 2003.

37. Economic commission for Africa. Africa: Integrating Gender in to structural Adjustment Policy and practice. Gender Response Development in Africa. April, 2011.

38. United Nations economic Commission for Africa: A study of the economic empowerment of women and their role in the Socio-Economic Development of Africa. Addis Ababa, Ethiopia; August 2009.

39. Choudhary M, Jain S, Saint V. Nutritional Status of Children of Working Mothers. Indi J Pediatr; 2003.

40. Nabaro D. Social, Economic, Health and Environmental determinants of Nutritional status. Food Nut Bull. 2007.

41. Welbourn HF, de Beer G. Trail of a kit for artificial feeding in tropical village homes. J Trop Pediat; 2005.

42. Kassie W. Kloos H. Modern Health Services in Ethiopia. In. Kloos H, Zein A Zein, editors: The ecology of Health and Disease in Ethiopia. Oxford Westview Press, 2008.

\section{Figures}




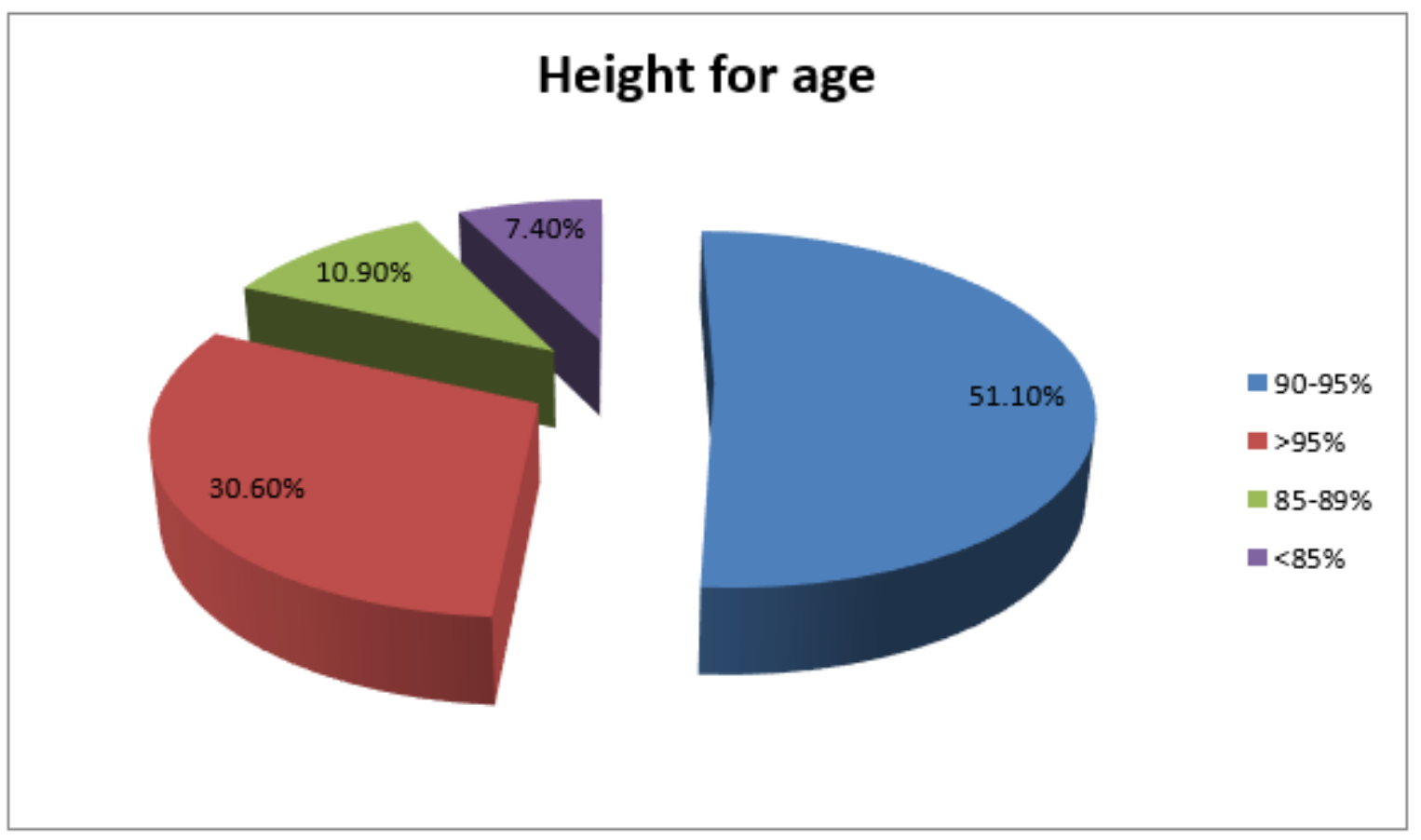

Figure 1

Height for age proportion of under five children, Jimma south west Ethiopia, May 2017 